\title{
SEJARAH PERPAT SERTA INDENTIFIKASI SOSIAL BUDAYA MASYARAKAT MELAYU BATAM 2000-2012
}

\section{PERPAT HISTORY AND IDENTIFICCATION OF MALAY SOCIOCULTURAL SOCIETY BATAM 2000-2012}

\author{
Desma Yulia ${ }^{1}$, Vivi Nalia ${ }^{2}$ \\ Program Studi Pendidikan Sejarah, FKIP, Universitas Riau Kepulauan, Batam, Indonesia \\ Email:.'desmayulia48@gmail.com, ${ }^{2}$ vivinalia@gmail.com
}

\begin{abstract}
Batam society shows pluralistic and different with Malay world existence. Perpat Perpat represent the real Malay world which has been lost. This reseach aims to know and understanding Perpat history parallel with social dynamic happened in early founding and understanding social cultural identification built by Perpat with historical perspective.This research uses history method. It done by 4 stages that are:1) Heuristic, that is sources collecting; 2) criticthat is sources validation; 3) interpretation that issourcesunderstanding; and 4) historiography that means historical writing process.This research results show that history of Perpat founding related with resistance of injustice to tempatan or local settlement. Moreover Perpat succeed show Malay identification process related with Malay social society in Batam area.
\end{abstract}

Kata kunci: Perpat, Malay, identification

\begin{abstract}
Abstrak
Masyarakat Batam menunjukan keberagaman dan berbeda dengan keberdaan dunia Melayu sebelumnya. Perpat menampilkan kembali suatu dunia Melayu sesungguhnya yang telah hilang. Tujuan penelitian ini adalah mengetahui dan memahmi sejarah Perpat seiring dengan dinamika sosial yang terjadi di masa awal pendiriannya dan memahami proses indentifikasi sosial budaya yang dibangun oleh Perpat dengan keterkaitannya dalam hal Indentifikasi Melayu dalam perspektif kesejarahan.Penelitian ini menggunakan metode sejarah. Metode ini dilakukan dengan 4 tahap yaitu : 1 ) Heuristik adalah pencarian dan pengumulan data; 2) kritik yang berupa oengujian data ; 3) interprestasi yaitu suatu penggambaran dan pemhan pada permasalahan yang akan dibahas ; 4) historiografi yang berarti proses penulisan sejarah. Hasil penelitian ini menunjukan bahwa sejarah pendirian Perpat berhubungan dengan resistensi atas ketidakadilan terhadap penduduk tempatan atau lokal. Selain itu, Perpat juga berhasil menujukan proses indentifikasi Melayu indentifikasi Melayu yang terhubung dengan sejarah masa lalu masyarakat Melayu di wilayah Batam.
\end{abstract}

Kata kunci : Perpat, Melayu, Indentifikasi

PENDAHULUAN

Pemahaman identifikasi Melayu di dalam lingkungan Kepulauan Riau sebaiknya didasarkan atas realitas di antara masyarakat Melayu itu sendiri. Minimnya pembahasan mendalam mengenai bagaimana masyarakat Melayu dilihat secara sosial menjadi persoalan bagaimana Melayu dipandang dinamis. Kondisi tersebut berdampak pada kekosongan pengetahuan dan pemahaman tentang realitas Melayu itu sendiri sehingga banyak di antara masyarakat kontemporer dan bahkan masyarakat Melayu itu sendiri menginterpretasikan Melayu hanya sekedar suatu wujud kultural berupa tari-tarian, pantun, dan wujud kesenian lainnya.

Berdasarkan hal tersebut tepat kiranya jika penelitian ini memfokuskan pada keberadaan salah satu organisasi Melayu khususnya di kota Batam, yang memiliki dampak sosial luas di antara masyarakat Melayu Batam kontemporer. Keberadaan Perpat 
sendiri rupanya menunjukkan adanya proses panjang yang bermula dari resistensi di antara penduduk Batam terhadap kebijakan negara. Sikap resisten ini didasari oleh sikap represif negara terhadap persoalan lahan yang menjadi tema-tema umum dalam berbagai konflik sengketa lahan di sepanjang rezim Orde Baru.

Sebaliknya masyarakat di Pulau Batam umumnya masih menggambarkan karakteristik masyarakat Indonesia. Proses perubahan masyarakat tradisional kepada masyarakat perkotaan di Pulau Batam sejak dekade 1970an rupanya tidak seiring dengan secepat masuknya arus modal dalam mendorong pertumbuhan dan perubahan ekonomi. Masyarakat perkotaan di Pulau Batam pada dekade tahun 1970an hingga 1980an sesungguhnya masih menggambarkan karakteristik tradisional. Pendirian Perpat di tahun 2000 dapat dijadikan patokan sebagai awal mula penelitian walaupun dalam banyak hal dapat ditarik jauh ke belakang untuk menelusuri lebih mendalam mengenai pembagai perubahan yang ada.Hal ini juga seiring dengan kemunculan pesat industrialisasi dan kapitalisasi yang diberagi dengan modernisasi dan demokratisasi melalui keterbukaan ide atas berbagai hal yang dalam banyak hal membangun Perpat itu sendiri. (Freddy Roeroe, dkk., 2010: 38).

\section{Sejarah dan Metodologi Sejarah Sosial}

Sejarah merupakan kejadian masa lampau yang tidak boleh dilupakan, karena tanpa adanya sejarah, manusia tidak akan ada pada zaman seperti sekarang ini. Kata sejarah secara harafiah berasal dari kata Arab yaitu šajaratun yang artinya pohon.Dalam bahasa Arab sendiri, sejarah disebut tarikh. Adapun kata tarikh dalam bahasa Indonesia artinya kurang lebih adalah waktu atau penanggalan. Kata Sejarah lebih dekat pada bahasa Yunani yaitu historia yang berarti ilmu atau orang pandai.Kemudian dalam bahasa Inggris menjadi history, yang berarti masa lalu manusia. Kata lain yang mendekati acuan tersebut adalah Geschichte yang berarti sudah terjadi. (Louis Gottschalk, 1985:26)

Tinjauan atas makna kebahasaan dari berbagai bahasa di atas dapat ditegaskan bahwa pengertian sejarah menyangkut dengan waktu dan peristiwa.Oleh karena itu masalah waktu penting dalam memahami satu peristiwa, maka para sejarawan 
cenderung mengatasi masalah ini dengan membuat periodisasi.Dengan demikian pengertian sejarah adalah sebagai berikut:

1. Jumlah perubahan-perubahan, kejadian atau peristiwa dalam kenyataan di sekitar.

2. Cerita tentang perubahan-perubahan, kejadian, atau peristiwa dalam kenyataan di sekitar..

3. Ilmu yang bertugas menyelidiki perubahan-perubahan, kejadian, dan atau peristiwa dalam kenyataan di sekitar.(Louis Gottschalk, 1985:26)

Bambang Purwanto menyebutkan sejarah sebagai sebuah pengetahuansangat tergantung pada wacana dan bentukrepresentasi antarteks pada konteks sosial dan institusional yang lebih luas di dalam atau melalui bahasa karena realitas objektif masa lalu telah berjarak dengan sejarah sebagai ilmu.Dalam konteks ini, sejarah sebagai ilmu tidak dapat disebutkan sebagai representasi langsung dari objektivitas.Berdasarkan cara berpikir di atas, sejarah sebagai kenyataan hanya merupakan sesuatu yang terjadi satu kali pada masa lalu dan tidak berulang,sedangkan sejarah sebagai sebuah rekonstruksi tertulis dan lisan yang kita kenal saat ini adalah produk dari bahasa, wacana, dan pengalaman sesuai dengan konteksnya. Hal itu berarti bahwa sebagai sebuah realitas, sejarah hanya ada pada masa lalu dan tidak mungkin dapat dijangkau oleh sejarawan.(Bambang Purwanto, 2001:29)

Rekonstruksi sejarah adalah produk subjektif dari sebuah proses pemahaman intelektual yangdilambangkan dalam simbol-simbol kebahasaan atau naratif dan dapat berubah dari waktu ke waktu, dari satu tempat ke tempat yang lain, atau dari satu orang ke orang yang lain. Sementara itu, pada saat yang sama sastra berhasil menampilkan citra dirinya sejajar sebagai sejarah karena mampu menghadirkan situasi faktual dari masa lalu sebagai sebuah narasi melalui imajinasi kebahasaannya. Hal itu 
berarti bahwa kebenaran sejarah maupun sastra adalah kebenaran relatif. Demikian juga tidak ada kebenaran absolut yang dapat ditemukan sehingga tidak selalu diperlukan teori penjelasan yang dapat diverifikasi melalui pengujian empirik. Bagi para sejarawan konvensional yang sangat percaya pada adanya kebenaran sejarah mutlak, hal itu tentu saja akan menimbulkan masalah pada tataran epistemologi. (Bambang Purwanto, 2001: 30)

Pembahasan mengenai sejarah sosial sebagaimana dalam kajian Perpat dalam penelitian ini yang terlepas dari konteks kekuasaan sebagaimana sejarah konvesional telah menjadi gelombang baru dalam penulisan sejarah di Indonesia.Sartono Kartodirdjo melalui studinya tentang pemberontakan petani Banten sebenarnya mulai mengalihkan sejarah Indonesia dari kajian yang hanya membahas tentang penguasa kolonial atau kerajaan menjadi pembahasan tentang masyarakat kebanyakan.Sartono juga mulai beralih dari tradisi penulisan sejarah yang berdasarkan filologi ke arah penulisan dengan pendekatan ilmu-ilmu sosial.Sejarah struktural atau penulisan sejarah dengan pendekatan multidimensional menjadi ciri penting perkembangan historiografi Indonesia selanjutnya.Akan tetapi, kehadiran historiografi yang didasarkan pada pedekatan ilmu-ilmu sosial yang multidimensional itu, ternyata belum mampu menyingkirkan kecenderungan rekonstruksi sejarah yang hanya menghujat kekuasaan kolonial atau memfokuskan diri pada peristiwa di sekitar kolonialisme.(Bambang Purwanto, 2001: 34)

Menurut Kuntowijoyo, historiografi dengan pendekatan ilmu-ilmu sosial hanya hidup di menara gading sehingga kebenaran ilmiah dari rekonstruksi sejarah hanya ada di kalangan kelompok tertentu, yaitu para sejarawan di perguruan-perguruan tinggi. Berbeda dengan Kuntowijoyo yang lebih melihat problematik historiografi yang dikembangkan oleh Sartono Kartodirdjo itu dalam konteks tidak adanya 
pengaruh intelektual terhadap kecenderungan umum penulisan sejarah Indonesia, beberapa kajian yang lebih kritis terhadap karya-karya sejarah yang menggunakan pendekatan ilmu-ilmu sosial ternyata menemukan adanya kecenderungan bahwa tradisi baru itu ma- sih tetap menempatkan sejarah Indonesiadalam pola pikir lama yang sangat menyederhanakan proses sejarah. Seperti telah disebutkan di atas, berbagai kajian yang berlabel multidimensional itu pun masih tetap memfokuskan ekplanasi historis sejarah Indonesia di sekitar kolonialisme sehingga menafikan buktibukti empirik tentang adanya independensi kausalitas yang menempatkan sejarah sebagai sebuah proses yang sebenarnya terjadi di sekitar masyarakatnya, padahal sebagai sebuah proses historis, sejarah pada masa kolonial tidak selalu identik dengan kekuasaan kolonial karena sejarah yang terjadi merupakan hasil dari interrelasi antarberbagai elemen yang ada pada waktu itu. (Kuntowijoyo,2008:24)

Ilmu sejarah memiliki berbagai cabang keilmuan yang terbagi dalam metodologi ilmu sejarah.Metodologi sejarah terbagi dan tergantung tema atau fokus permasalahannya.Salah satu metodologi sejarah yang umum diketahui dalam penelitian sejarah dan sesuai dengan penelitian ini adalah metodologi sejarah sosial.Adapun metodologi sejarah sosial mempunyai bahan garapan yang sangat luas dan beraneka ragam.Pembacaan sejarah sosial, setidaknya dapat ditemukan enam model yang masing-masing, yaitu :

1. Model evolusi; untuk menunjukkan jenis penulisan yang melukiskan perkembangan sebuah masyarakat berdiri sampai menjadi masyarakat yang kompleks.

2. Model lingkaran sentral; model ini menuliskan sebuah masyarakat atau kota tetapi dimulai dari titik yang sudah ada bukan dari awalnya. 
3. Model interval; merupakan kumpulan dari lukisan sinkronis yang diurutkan dalam kronologis sehingga tampak perkembangannya walaupun tidak nampak secara jelas hubungan sebab akibatnya.

4. Model tingkat perkembangan; model ini penerapan dari teori perkembangan masyarakat yang diangkat dari sosiologi.

5. Model jangka panjang menengah pendek; yang diambil dari teori Fernand Braudel dalam menangani sejarah sosial yang membagi sejarah dalam tiga macam keberlangsungan.

6. Model sistematis; model ini untuk menelusuri sejarah sosial dalam arti perubahan sosial. (Sartono Kartodirdjo, 1993: 26)

Berkenaan dengan tema penelitian ini tentang Perpat sebagai suatu organisasi sosial maka model yang sesuai dengan fokus penelitian ini adalah model nomor empat atau umum disebut model tingkat perkembangan.Model ini sendiri menempatkan fokus dan pembahasan terhadap Perpat dengan perlakuannya sebagai organsisasi sosial berkenaan dengan konsep sosiologi.

\section{Dinamika dan Mobilitas Sosial}

Dalam memahami dinamika sosial budaya ditentukan oleh perubahan dapat ditentukan melalui arah dalam kerangka sosio historis. Meskipun pandangan mengenai sejarah sebagai siklus dominan di kalangan pemikir Cina, Yunani, dan Romawi, namun ada sejumlah pemikir yang melihat jalannya perubahan sosial secara berlainan, yakni menurut proses garis lurus (linear), seperti di dunia barat modern, berkembang pemikiran bahwa perubahan sosial berkembang sesuai garis lurus dan menuju pada kemajuan. Di dunia Barat modern ide kemajuan menjadi tema dominan dan hanya abad kini saja kemajuan itu muncul dalam pikiran manusia.Pada dasarnya pola evolusi manusia dan masyarakat berlangsung lambat, 
namun pasti, berkembang menuju keadaan yang lebih baik.(Lawang, 1986: 9.9)

Selain itu adapula yang menyatakan kemajuan dengan penuh semangat dan pujian. Ia mengatakan tidak ada hambatan yang melekat dalam kesempurnaan kemampuan manusia. Kesempurnaan kemampuan manusia benar-benar tak terbatas kecuali karena terbatasnya usia bumi tempat kita hidup. Dalam menentukan perubahan sosial, Comte mengemukakan tiga tingkatan perkembangan yang sejalan dengan tiga tingkat perkembangan pemikiran manusia dan menyebutnya sebagai hukum fundamental yang dilewati secara berurutan. Ketiganya adalah tingkat teologis (khayalan), tingkat metafisika (abstrak), dan tingkat ilmiah (positif). Pada tingkat teologis, manusia berfikir bahwa apa pun yang terjadi dalam kehidupan manusia adalah kehendak Tuhan. Dalam perkembangan selanjutnya manusia mulai berfikir metafisika yang menyatakan segala yang terjadi dalam kehidupan manusia dikarenakan alam semesta.Perkembangan terakhir yaitu tingkatan ilmiah yang menyatakan bahwa hal-hal yang terjadi dalam kehidupan manusia tidaklah disebabkan oleh satu faktor, untuk itu kita perlu mencari penyebab fenomena perubahan itu.Tingkatan ilmiah menggunakan nalar dan pengamatan dalam berpikir untuk dapat mengetahui perubahan yang terjadi dalam masyarakat. (Pattinasarani, 2012: 34)

\section{Identifikasi Melayu Sebagai Kesatuan Sosial Budaya}

Proses identifikasi Melayu tidak terlepas dari bagaimana masyarakat Melayu merepresenatasikan dirinya kepada diri dan lingkungan sosial budaya Melayu, serta kepada masyarakat di luar lingkungan kebudayaan Melayu. Proses identifikasi tersebut tidak terlepas dari proses pemaknaan Melayu sebagai suatu identitas sosial budaya.

Proses identifikasi makna Melayu sesungguhnya telah coba diidentifikasikan dalam berbagai kajian. Akan tetapi sifatnya yang diskontinuitas atau 
terputus dari suatu period eke periode lainnya menimbulkan suatu persoalan tentang bagaimana seharusnya identifikasi Melayu disikapi. Pola acak identifikasi Melayu sesungguhnya dapat dilihat dalam kerangka periode dari pemknaan Melayu itu sendiri dan hal ini menunjukkan adanya keterkaitan makna dari suatu makna di periode tertentu kepada makna Melayu di periode berikutnya.

Proses pemaknaan Melayu dapat dilihat dalam bentuk pembagian periodesasi yang terbagi menjadi 3 kurun waktu periode yaitu kontemporer, mediaval, dan klasik. Ketiga bentuk pemaknaan itu sendiri tidak terlepas dari nilai sosial budaya dan masyarakat pendukungnya di masing-masing periode.

Jika mengurutkan proses waktu dari yang terdahulu hingga kini, proses pemaknaan Melayu pertama adalah yang bersifat klasik. Dalam bagian ini pemaknaan terjadi sejak proses penciptaan istilah Melayu dan penyebarannya di masa klasik kerajaan Budha Sriwijaya.Penggunaan kata Melayu di dunia kuno sesungguhnya telah muncul dalam berbagai catatan.Umumnya Melayu ditekankan kepada suatu penyebutan geografis. Penyebutan Melayu tertua hadir di kitab VayuPurana dengan adanya penyebutan mengenai Malayadvipa (Malayadwipa = Tanah Malaya) yang berarti "dataran pulau-pegunungan" dan digambarkan sebagai salah satu provinsi di kepulauan sebelah timur yang bersifat mistis namun berlimpahan emas dan perak. Selain itu beberapa ahli menyamakan istilah Melayu dengan Sumatra, tetapi beberapa ilmuwan India mempercayai istilah Melayu mengacu pada Semenanjung Malaya yang sangat bergunung-gunung, sedangkan Sumatra lebih tepat dihubungkan dengan Suvarnadvipa (Suwarnadwipa $=$ Tanah Sumatra). (Slamet Mulyana, 2005: 23)

\section{METODOLOGI}

\section{Jenis Penelitian}

Mengingat penelitian ini berbasis landasan filosofis kebudayaan maka 
penelitian ini adalah penelitian sejarah dengan pendekatan ilmu sosial.Adapun penelitian sejarah sosial terkait dengan pemahaman ilmu-ilmu sosial yaitu sosiologi.Salah satu karakteristik dari penelitian ini adalah sifatnya yang diakronis yang lebih mendekatkan diri kepada ilmu sejarah daripada rumpun ilmu antropologi yang umumnya bersifat sinkronis, serta sikap apriorinya yang menghindari generalisasi. Selain itu proses penelitian dan penulisan memiliki unsur naratif yang jauh lebih kental dibandingkan eksplorasi deskriptif seperti ilmu-ilmu sosial atau antropologi. Akan tetapi unsur penting dalam pencarian makna dan nilai seperti dalam ilmu antropologi tetap merupakan unsur menonjol dan kunci menuju pemahaman secara holistik. (Kuntowijoyo, 1994: 25)

Berdasarkan uraian di atas, maka penelitian mengenai sejarah Perpat dan identifikasi sosial budaya masyarakat Melayu Batam. Ulasan dan pemaknaan atas identifikasi sosial budaya akan disertai dengan ulasan mengenai identifikasi sosial budaya di dalam keanggotaan.

\section{PEMBAHASAN}

\section{Sejarah Perpat}

Seperti telah dijelaskan di bagian sebelumnya bahwa kesadaran Melayu sebagai ikatan kolektif atau bersama dituangkan dalam beberapa bidang.Salah satunya adalah pembentukan organisasi.Dari berbagai organisasi yang menunjukkan identitas kemelayuan, Perpat menjadi tema penelitian ini. Hal ini didasarkan atas beberapa ciri 
khas Perpat sebagai salah satu organisasi kepemudaan di kota Batam yang dianggap dapat mewakili suara orang Melayu atau penduduk yang lebih dahulu tinggal di kota Batam

Sejarah perpat sendiri tidak terlepas dari perjalanan sejarah panjang wilayah di Batam yang menjadi bagian tidak terpisahkan dari perjalanan panjang pulau Batam dan sekitarnya. Dengan demikian di bawah ini akan menuliskan secara panjang lebar perjalanan sejarah terkait dengan kemunculan Batam sebagai wilayah Free Trade Zone (FTZ) oleh pemerintah Indonesia sejak tahun 1974.

Sebelum tahun 1974, wilayah Batam masih dianggap seperti bagian Indonesia lainnya.Tidak ada yang istimewa dari kedudukan Batam di mata Negara Indonesia pada masa tersebut terkecuali soal pertahanan mengingat munculnya konflik dengan Malaysia pada awal dekade 1960an.

Akan tetapi kedudukan Batam yang tepat berada di jalur perlintasan perdagangan dunia membuat Batam menjadi salah satu bagian menarik untuk dibawa ke arah pembangunan ekonomi.Hal ini sesungguhnya mengikuti langkah pemerintah colonial yang telah terlebih dahulu membangun kawasan industri perminayakan di pulau Sambu.

Hal ini dimulai dengan pembangunan FTZ yang diresmikan oleh Presiden Soeharto pada tahun 1974 melalui pimpinan FTZ yaitu J. B. Sumarlin.Tujuan utamanya adalah persaingan ekonomi dengan tetangga Indonesia, Singapura, sebagai salah satu pusat perdagangan dan industri di Asia Tenggara.Pemberlakuan FTZ sesungguhnya masih sangat terbatas disebabkan oleh minimnya infrastruktur di Pulau Batam itu sendiri. Lambannya laju pemerintah Orde Baru dalam membangun FTZ berdampak terhadap tersendatnya arus investasi ke Pulau Batam sehingga Batam yang sebelumnya diharapkan mampu menyaingi Singapura justru lebih berperan sebagai tempat penampungan investasi modal di Singapura yang mencari tenaga kerja dan biaya produksi lebih rendah dibanding Singapura. 


\section{Identifikasi Melayu dalam Perpat}

Fokus pembahasan ini adalah untuk melihat seperti apakah yang dianggap sebagai Melayu oleh Perpat.Perpat sendiri tak melihat bahwa Melayu sebagi subyek utama tetapi dianggap sebagai tempata dan orang asli Batam. Pembahasan dilakukanpada gagasan Perpat tentang tempatan mirip dengan identifikasi Melayu.

Gagasan Perpat tentang tempatan dimasukan kepada struktur organisasinya.Menurut Perpat untuk menjadi anggota perpat digolongkan kepada tiga bagian yaitu kategori A, B, dan C. Ketiga kategori ini dibedakan dengan lama waktunya.

Kategori A ditujukan bagi warga yang sudah tinggal di Batam lebih dari 15 tahun atau dilahirkan di wilayah Batam. Kategori B ditujukan bagi warga yang sudah tinggal di Batam antara 5 hingga 15 tahun, dan kategori $\mathrm{C}$ ditujukan warga yang tinggal di Batam kurang dari 5 tahun.

Penjelasan untuk kategori A adalah sebagai berikut:

"Kategori A ditujukan untuk yang tinggal di Batam lebih dari 15 tahun. Maksudnya jika sudah makan dan minum di Batam selama itu, terus beranak pinak di sini, itu kan namanya sudah menjadi warga sini. Misalnya ada orang Jawa tinggal di sini selama 20 tahun.Hubungan dengan Jawa memang tidak terputus tapi dunianya dia sudah dunia Batam bukan Jawa. Cara berbicaranya beda dengan orang Jawa ada kemelayu-melayuannya. Apalagi anaknya dilahirkan di Batam pula.Ya itu berarti sudah jadi orang sini." (wawancara dengan Jufri Bakri, 2 Juni 2014)

\section{KESIMPULAN DAN SARAN}

Perpat sebagai suatu organisasi tidak terlepas dari keberadaan individu yang ada di dalamnya.Dinamika dan sejarah pendirian Perpat tidak terlepas dari keberadaannya pada penentangan pengambilaliahn paksa oleh negara yang dalam hal ini diwakili oleh pemerintah otorita. Pemicu utama yang membangkitkan gerakan kepemudaan Perpat adalah adanya kasus sengketa lahan di Tanjung Uma.Sengketa ini sendiri merupakan rangkaian panjang berbagai sengketa lahan antara masyarakat dengan negara melalui pengambilalihan sepihak.oleh negara. Pendirian perpat juga dianggap sebagai perwakilan 
atas resistensi atau penolakan masyarakat atas keterpinggiran mereka. Hal tersebut tentu menyebabkan banyak warga yang memiliki berbagai dampak dari upaya pengambilalihan lahan kemudian merasakan bahwa perasaan senasib akan membuat mereka menjadi lebih kuat.

1. Keberhasilan Perpat dalam mendesak pihak otoritas atau penguasa untuk mendengarkan dan mengaspirasikan kepentingan masyarakat tampaknya lebih dari sekedar berhasil.Perpat memiliki posisi tawar untuk menandingi kebijakan pemerintah yang dirasakan dapat merugikan tempatan.Tetapi hal tersebut justru membawa Perpat pada perpecahannya.Keberhasilan Perpat secara politis juga menunjukan adanya kemampuannya dalam posisi politik.Kondisi tersebut menyebabkan Perpat terlibat pada politik praktis dan menyebabkan perpecahan Perpat itu sendiri.Keberadaan Perpat kemudian lebih terkotakkotakan pada persoalan politik terutama sejak paruh kedua dekade 2000-an.

2. Berbeda dengan kondisi riil Perpat yang mengalami pasang surut, secara ideologis Perpat menunjukan banyak sudut pandang Melayu.Hal ini dapat dilihat kembali pada realitas awal sejarah penduduk warga di sekitar Kepulauan Batam. Kedatangan berbagai penduduk pendatang di wilayah sekitar Batam pada masa lalu mununjukan adanya meleburnya masyarakat pendatang dengan masyarakat lokal atau yang kemudian dikenal sebagai tempatan. Hal ini dapat dilihat dari adanya kedatangan masyarakat Bugis di abad ke-16 hingga ke-19 yang di masa kini benar-benar telah dianggap sebagai bagian masyarakat lokal atau tempatan dengan berkebudayaan Melayu.Ungkapan bahwa menjadi Melayu adalah dengan beragama Islam, berbahasa Melayu, dan berkebudayaan Melayu rupanya benarbenar terjadi pada masyarakat pendatang Bugis dan keturunannya. Hal serupa tetapi berbeda pelaksanaannya juga terjadi pada Perpat.Meskipun Perpat dimotori 
oleh berbagai pendatang berkebudayaan Melayu, ideology awal kemelayuan Perpat sangat menonjol pada pembentukan keanggotaan Perpat. Dengan adanya kategori A, B, dan C pada Perpat menunjukan bahwa Perpat berupaya menunjukan apakah individu tersebut telah benar-benar menjadi atau berperlikau layaknya orang Melayu atau tidak. Kelanjutan pemikiran Melayu tersebut semakin membuktikan bahwa peristiwa sejarah mungkin tidak akan terjadi dua kali, tetapi sejarah akan berulang dalam versi berbeda.

\section{REFERENSI}

Angelbeek, C. van. 1862. Korte Schets van het Eiland Lingga en Deszelfs Bewoners. Batavia: Batavia Genootschap van Kunsten en Wetenschappen.

Chou, C. 2004. Money, Magic, and Fear: Identity and Exchange Amongst The Orang Suku Laut (Sea Nomads) and Other Groups of Riau and Batam, Indonesia. London: Routledge.

Aritenang, Wendy. (ed.). 2003. Menuju Batam Yang Lebih Cemerlang: Kumpulan Sumbangan Pemikiran Tentang Masa DepanBatam Yang Cemerlang. Jakarta: Khanata, Pustaka LP3ES.

BP Batam. 2008. Batam Free Trade Zone, Sebuah Kit Pembangunan Ekonomi. Batam: BP Batam.

Cartesao, Antonio. 1944. The Suma Oriental of Tomi Pires, An Account of the East, From the Red Sea to Japan, Written in Malacca 1512-1511 and the Book of Fransisco Rodrigues. Lessing-Druckerel: Wiesbaden.

Dora Lisya Fika, "Sejarah Belakang Padang Sebagai Wilayah Buffer Zone 2000-2013", Skripsi Program Studi Pendidikan Sejarah universitas Riau Kepualauan 2013.

Indera Ratna Irrawati Pattinasarani, "Mobilitas sosial vertikal antar generasi: kajian terhadap masyarakat kota di Provinsi Jawa Timur". Disertasi Sosiologi FISIP UI 2012.

Gottschalk, Louis. 1985. Mengerti Sejarah. Penerjemah: Prof. Nugroho Notosusanto. Jakarta: UI Press.

Kartodirdjo, Sartono. 1993. Pendekatan Ilmu Sosial Dalam Ilmu Sejarah. Yogyakarta: UGM Press.

Lawang, Robert M. Z. 1986. Buku Materi Pokok Sistem Sosial Indonesia I. Jakarta: Penerbit Karunika Jakarta.

Purwandari, "Perubahan sosial di Kampung Tanjung Uma 1999-2012”, Skripsi Program Studi Pendidikan Sejarah Universitas Riau Kepulauan 2013.

Roeroe, Freddy, dkk. 2010. Batam, Komitmen Setengah Hati. Bekasi: Aksara Karunia. Stephen P. Robbins. 2002. Prinsip-Prinsip Prilaku Organisasi Sosial. Jakarta: Erlangga.

Slamet Mulyana. 2005. Menuju Puncak Kemegahan: Sejarah Kerajaan Majapahit. Jakarta: LKIS.

Schnitger, F.M., Christoph von Fürer-Haimendorf, G. L. Tichelman. 1989. Forgotten Kingdoms in Sumatra. Oxford: Oxford University Press. 